\title{
Influence of Fertilizers on the Yield of the Plamar Variety of Tomatoes on a Coto Clay
}

\author{
Pablo Landrau, Jr., and George Samuels ${ }^{1}$
}

\section{INTRODUCTION}

Most of the tomatoes and tomato products consumed in Puerto Rico are imported. In the fiscal year 1950-51, $\$ 2,400,000$ was spent on imported tomato pastes and purees (1), ${ }^{2}$ whereas in the same period a farm income of only $\$ 893,000$ was realized by the Puerto Rican farmers from growing tomatoes. The area in tomatoes in Puerto. Rico for 1950-51 was 2,694 acres with an average yield of 64.3 hundredweights of tomatoes per acre. . The expansion of tomato production in Puerto Rico has been recommended primarily to supply our own needs. It has been claimed that our farmers must improve their cultivation practices to do this profitably. These practices include the use of better lands, larger plantings, irrigation, improved varieties, application of adequate fertilizers, and control of insects and diseases by spraying. (1).

It is the purpose of this article to report how fertilizers influence the yields of the Plamar variety of tomatoes on Coto clay, a soil much used for tomato production.

\section{PROCEDURE}

To study the influence of fertilizers on the yield of tomatoes, a field experiment was planted August 15, 1952, on a Coto clay at the Isabela Substation. The Isabela area is located on the northwestern corner of Puerto Rico and has an average altitude of about 300 feet above sea level. The land is devoted mainly to sugarcane. Other crops such as pineapple, tomatoes, peppers, tobacco, cotton, and corn do well, if irrigated. The land is owned mainly by farmers with small acreages. The average yearly rainfall is 66 inches, precipitation being considerably below average during the winter months. Because of a dry spell, the 15.57 inches of rain which fell during the 3-month experimental period was augmented with four irrigations.

Coto clay is a permeable yellowish-colored clay derived from Tertiary limestone. Its $\mathrm{pH}$ ranges normally from 5.0 to 6.5 . A description of a soil

\footnotetext{
${ }^{1}$ Assistant Agronomist and Agronomist, respectively, Agricultural Experiment Station, University of Puerto Rico, Río Piedras, P. R. The authors wish to thank Rafael Garcia, former Research Assistant in Agronomy at the Isabela Substation and other members of the Substation for their help in the fieldwork.

${ }^{2}$ Numbers in parentheses refer to Literature Cited, pp. 82-3.
} 
profile of Coto clay can be found in a previous publication by the authors. (2).

The experiment here reported included 16 fertilizer treatments replicated 6 times in a triple-lattice field design. The size of the plots was 10 by 12 feet, or about one three-hundred-and-sixty-third of an acre in area. A total of 15 plants per plot were planted in rows 4 feet apart with a distance of 2 feet between plants, and using the hill system of planting. The tomato variety used was the Plamar which is blight-resistant and outyields the imported varieties during the summer months.

The fertilizer treatments consisted of applying various quantities of the major fertilizer elements and of two minor elements. Filter-press cake; a byproduct of the sugarcane mills, was also tried as a soil ameliorator, both by itself and in combination with chemical fertilizers. All fertilizer, except for the filter-press cake, was applied after the plants were set out in the field. Filter-press cake was placed in the hole before planting, and for one split-fertilizer application, followed by another application 6 weeks after the other plants were fertilized.

The experiment was planted on August 25, 1952, and was harvested on October 15, 1952, and on November 17, 1952. At time of harvest, the pickings were divided into commercial marketable size (above 0.2 pound) and culls (less than 0.2 pound) and unmarketable. Besides weight of tomatoes, counts of tomatoes per plot were made to determine the mean weight of the commercial fruit.

\section{RESULTS}

NITROGEN

The yield of tomatoes was definitely increased by the use of nitrogen fertilizers. The use of 100 pounds of $N$ per acre gave an increase in marketable tomatoes of 41.9 hundredweights, or 97 percent over the treatment where no nitrogen was applied (table 1 , treatment 2 minus treatment 1 ). The use of 100 pounds of $N$ per acre also reduced the percentage of culls from 46 to 38 and increased the mean weight of the commercial fruit from 2.29 to 2.45 ounces.

When 200 pounds of $\mathrm{N}$ per acre was applied, there was a slight decrease of about 7 hundredweights in yield over the 100-pound N-per-acre treatment. The 200-pound N-per-acre treatment also raised the percentage of culls to 44 as compared with 38 with the 100-pound N-per-acre treatment, and slightly reduced the mean fruit weight. For the conditions of this experiment, when sufficient $\mathrm{P}_{2} \mathrm{O}_{5}$ and $\mathrm{K}_{2} \mathrm{O}$ are present, 100 pounds of $\mathrm{N}$ per acre appeared to be sufficient to produce optimum yields of Plamar tomatoes. 
TABLE 1.-Influence of various fertilizer treatments on the yield of Plamar tomatoes

\begin{tabular}{|c|c|c|c|c|c|c|c|c|}
\hline \multirow{2}{*}{$\begin{array}{c}\text { Treatment } \\
\text { No. }\end{array}$} & \multicolumn{3}{|c|}{ Treatment per acre of- } & \multicolumn{3}{|c|}{ Yield of tomatoes per acre } & \multirow{2}{*}{ Culls } & \multirow{2}{*}{$\begin{array}{l}\text { Mean weight of } \\
\text { commercial fruit }\end{array}$} \\
\hline & $\mathrm{N}$ & $\mathrm{P}_{2} \mathrm{O}_{5}$ & $\mathrm{~K}_{2} \mathrm{O}$ & $\begin{array}{c}\text { Commer- } \\
\text { cial size }\end{array}$ & Culls & $\begin{array}{c}\text { Total } \\
\text { production }\end{array}$ & & \\
\hline & Pountds & Pounds & Pounds & Cwt. & Cwt. & Cwt. & Percent & Ounces \\
\hline 1 & 0 & 200 & 200 & 43.2 & 37.3 & 80.5 & 46 & 2.29 \\
\hline 2 & 100 & 200 & 200 & 85.1 & 51.3 & 136.4 & 38 & 2.45 \\
\hline 3 & 200 & 0 & 200 & 47.5 & 37.2 & 84.7 & 44 & 2.36 \\
\hline 4 & 200 & 100 & 200 & 57.1 & 48.1 & 105.2 & 46 & 2.33 \\
\hline 5 & 200 & 200 & 0 & 86.3 & 59.1 & 145.4 & 41 & 2.25 \\
\hline 6 & 200 & 200 & 100 & 76.9 & 51.4 & 128.3 & 40 & 2.44 \\
\hline 7 & 200 & 200 & 200 & 78.4 & 58.3 & 136.7 & 43 & 2.34 \\
\hline 8 & 0 & 0 & 0 & 19.1 & 18.4 & 37.5 & 49 & 2.41 \\
\hline $9^{1}$ & 0 & 0 & 0 & 38.5 & 30.1 & 68.6 & 44 & 2.23 \\
\hline $10^{2}$ & 0 & 0 & 0 & 41.1 & 42.9 & 84.0 & 51 & 2.20 \\
\hline $11^{1}$ & 100 & 200 & 200 & 86.6 & 48.4 & 135.0 & 36 & 2.49 \\
\hline $12^{2}$ & 100 & 200 & 200 & 106.3 & 52.6 & 158.9 & 33 & 2.48 \\
\hline $13^{3}$ & 200 & 200 & 200 & 63.0 & 43.4 & 106.4 & 41 & 2.29 \\
\hline $14^{4}$ & 200 & 200 & 200 & 57.2 & 43.3 & 100.5 & 43 & 2.30 \\
\hline $15^{5}$ & 200 & 200 & 200 & 92.9 & 50.0 & 142.9 & 35 & 2.53 \\
\hline
\end{tabular}

Least significant difference needed between treatment means:

\begin{tabular}{l|l|l|l|r|r}
\hline 5-percent level: & 21.2 & 12.6 & 30.9 & & 0.22 \\
1-percent level: & 28.2 & 16.7 & 41.1 & & .29 \\
\hline
\end{tabular}

1 Plus 10 tons filter-press cake.

2 Plus 20 tons filter-press cake.

${ }^{3}$ Plus 50 pounds borax.

${ }^{4}$ Plus 100 pounds $\mathrm{MgO}$.

5 Fertilizer applied in 2 applications, one-half when plants were set in field, onehalf 6 weeks after this.

\section{PHOSPHORUS}

The use of phosphate fertilizers increased yields of tomatoes very significantly. The use of 100 pounds of $\mathrm{P}_{2} \mathrm{O}_{5}$ per acre gave an increase of about 10 hundredweights of commercial tomatoes, whereas 200 pounds of $\mathrm{P}_{2} \mathrm{O}_{5}$ per acre raised yields nearly 20 hundredweights over the 100 -pound $\mathrm{P}_{2} \mathrm{O}_{5}$ per-acre treatment (treatment 5 minus treatment 3 ). The percentage of culls rose slightly when 100 pounds of $\mathrm{P}_{2} \mathrm{O}_{5}$ per acre were used and then decreased somewhat more with 200 pounds of $\mathrm{P}_{2} \mathrm{O}_{5}$ per acre. The mean weight of commercial fruit showed no appreciable change attributable to phosphate applications. The total weight of tomatoes produced per acre responded significantly only to the application of 200 pounds of $\mathrm{P}_{2} \mathrm{O}_{5}$ per acre. 
The use of phosphate fertilizers for tomato production in Coto clay soils seems to be essential. This need of phosphate fertilizers in Coto clay has been demonstrated for other crops also, such as sugarcane (2), red beans (4), potatoes (3), eggplants (7), cucumbers (6), and corn (8). This high demand for phosphorus has also been observed in other areas for shortgrowing crops.

\section{POTASSTUM}

Potash fertilizers produced no significant increase in yield of tomatoes. This was true for commercial fruit, culls, and total production per acre. This lack of response of the Coto clay to potash applications has been noted before for sugarcane (2), potatoes (3), red beans (4), and cucumbers (6).

\section{ETLTER-PRESS CAKE}

Filter-press cake, an organic byproduct from the sugar mills of Puerto Rico, proved to be of definite value in fertilizing tomatoes grown on a Coto clay. When used alone, 10 tons of the filter-press cake per acre increased total tomato yield in a barely significant way over that of the no-fertilizer treatment (treatment 9 minus treatment 8). However, with 20 tons of -filter-press cake per acre, significant yield increases of commercial tomatoes of 22 hundredweights were realized (treatment 10 minus treatment 8 ). With the use of filter-press cake alone, the mean weight of commercial fruit was reduced from 2.41 to 2.20 ounces (treatment 8 compared with treatment 10).

When combined with commercial fertilizer, filter-press cake gave impressive increases in yield of tomatoes per acre. The combination of 100 pounds of $\mathrm{N}$ and 200 pounds each of $\mathrm{P}_{2} \mathrm{O}_{5}$ and $\mathrm{K}_{2} \mathrm{O}$ per acre with 20 tons of filterpress cake gave a yield increase of 21.2 hundredweights of commercial tomatoes per acre (treatment 12 minus treatment 2). The use of 10 tons of filter-press cake plus treatment 2 did not give any significant yield increases. The percentage of culls was reduced where the filter-press cake was used in combination with commercial fertilizer, and the mean weight of commercial fruit remained high.

The value of filter-press cake for growing tomatoes has been shown by other workers $(5,6)$. It should be stressed here that maximum benefit was realized from the filter-press cake as a fertilizer source because of the fact that the Coto clay did not need additional sources of potassium. Filterpress cake averages about 2.50 percent of $\mathrm{N}$ and $\mathrm{P}_{2} \mathrm{O}_{5}$ but contains only traces of $\mathrm{K}_{2} \mathrm{O}$. Since the tomatoes responded significantly to nitrogen and phosphate and not to potash fertilizers, the filter-press cake was proved to be a good fertilizer source for tomatoes on a Coto clay. On other soils which 
require additional potash fertilizers the filter-press cake would have to be re-enforced with potash to give good results for tomatoes.;

\section{MAGNESIUM AND BORON}

The application of the minor elements magnesium or boron as magnesium oxide and borax failed to produce any significant increases in yields. The use of 100 pounds of $\mathrm{MgO}$ per acre actually significantly reduced yields of commercial tomatoes 21.2 hundredweights (treatment 7 minus treatment 14). Neither percentage of culls nor mean weight of commercial fruit were appreciably influenced by the magnesium or boron treatments (compare treatments 13 and 14 with 7).

\section{NUMBER OF APPLICATIONS}

The application of the fertilizer in two portions instead of one did not produce any significant increase in yield of commercial tomatoes (treatment 15 minus treatment 7). The percentage of culls produced dropped from 43 with one fertilizer application to a low of 35 with two applications. There was no significant difference in mean weight of fruit attributable to the two fertilizer applications.

The Coto clay has high permeability (2) and water drains through this soil very rapidly. This high permeability, coupled with the high rainfall and irrigation may, however, leach out some of the fertilizer nutrients applied to the soil and a split application of fertilizer may possibly be a better practice on Coto clay.

\section{PRACTICAL RECOMMENDATIONS.}

For the Plamar variety of tomatoes growing on a Coto clay in Puerto Rico the following fertilizer recommendations may be followed;

Nitrogen: $100-150$ pounds of $\mathrm{N}$ per acre.

Phosphorus: 150 to 200 pounds $\mathrm{P}_{2} \mathrm{O}_{5}$ per acre.

Potassium: 0-50 pounds of $\mathrm{K}_{2} \mathrm{O}$ per acre:

Filter-press cake: $15-20$ tons per,acre.

The filter-press cake should be applied in the hole at the time of planting.

\section{SUMMARY}

The use of various fertilizer treatments on the Plamar variety of tomatoes growing on a Coto clay at the Isabela Substation revealed that:

1. The use of 100 pounds of $N$ per acre gave significantly higher yields of commercial tomatoes per acre than either none or 200 pounds of $\mathrm{N}$ per acre.

2. Phosphate fertilizers increased tomato yields, the highest yields being obtained with 200 pounds of $\mathrm{P}_{2} \mathrm{O}_{5}$ per acre. 
3. There was no response to potash fertilizers.

4. The use of 20 tons of filter-press cake per acre gave significant increases in yields over the no-fertilizer treatment.

5. When 20 tons of filter-press cake were used combined with 100 pounds of $\mathrm{N}$ and 200 pounds each of $\mathrm{P}_{2} \mathrm{O}_{5}$ and $\mathrm{K}_{2} \mathrm{O}$ per acre, the yields obtained were superior to those when the filter-press cake or chemical fertilizer were used alone.

6. No yield increases were obtained with magnesium and boron additions to the N-P-K fertilizer applications.

\section{RESUMEN}

Se compendia, a continuación, los resultados obtenidos del uso de varios tratamientos de abono aplicados a siembras experimentales de tomate, variedad Plamar, en un suelo del tipo Coto arcilloso en la Subestación Experimental de Isabela.

1. La aplicación de 100 libras de nitrógeno por acre produjo significativamente mayores rendimientos de tomates comerciales por acre, que cuando no se aplicó nitrógeno o se aplicó este elemento a razón de 200 libras por acre.

2. El uso de abonos fosfatados aumentó la producción de tomates, obteniéndose los mayores rendimientos cuando se aplicaron 200 libras de $\mathrm{P}_{2} \mathrm{O}_{5}$ por acre.

3. La cosecha no respondió a las aplicaciones de potạsa.

4. La aplicación de cachaza a razón de 20 toneladas por acre, motivó aumentos significativos en los rendimientos, al compararse con los tratamientos en los cuales no se usó abono alguno.

5. Cuando se combinaron 20 toneladas de cachaza con 100 libras de nitrógeno por acre o con 200 libras de $\mathrm{P}_{2} \mathrm{O}_{5}$ y $\mathrm{K}_{2} \mathrm{O}$ por acre, los rendimientos fueron superiores comparados con los tratamientos que recibieron cachaza o abonos químicos solamente.

6. No se obtuvieron aumentos en los rendimientos con la adición de magnesio o boro a los abonos químicos (N-P-K).

\section{LITERATURE CITED}

1. Koenig, N., A comprehensive agricultural program for Puerto Rico, U.S.D.A. in cooperation with the Commonwealth of Puerto Rico, Washington, D. C., 1953.

2. Landrau, P., and Samuels, G., Response of four sugarcane varieties to fertilizers during the first Isabela cycle, 1946-51, J. Agr. Univ. P. R. 38 (2) 73-95, 1952.

3. Landrau, P., Rodríguez, J. P., Samuels, G., Alers-Alers, S., and Gandía-Caro, R. Effect of spacing and fertilization on the yield of potatoes, J. Agr. Univ. P.R. 39 (2) $100-10,1955$.

4. Méndez, F., Fertilizer test with native red beans, Annual Report of the Agr. Expt. Sta. Univ. of P. R., p. 88, 1938-39. 
5. Locsin, C. L., Filter cake as fertilizer, Victorias Milling Co., Inc. (Victorias, Negros Occidental, Philippines) Exp. Station Press Release No. 3, Sept. 1953.

6. Riollano, A., The value of filter-press cake as a fertilizer for vegetable crops, preliminary trials with tomatoes and cucumber, Proc. Amer. Soc. Hort. Sci. 42 547-50, 1943.

7. Serrano, L. A., Annual Report Isabela Substation, Annual Report of the Agr. Expt. Sta. Univ. of P. R., Río Piedras, pp. 161-62, 1936-37.

8. Serrano, L. A., Fertilizer test with corn, Annual Report of the Agr. Expt. Sta. Univ. of P. R. p. 43, 1939-40. 